\title{
Role of Oxytocin in the Pathogenesis and Modulation of Borderline Personality Disorder: A Review
}

Muhammad Youshay Jawad ${ }^{1}$, Bakhtawar Ahmad ${ }^{1}$, Ali Madeeh Hashmi ${ }^{1}$

1. Academic Department of Psychiatry and Behavioral Sciences, King Edward Medical University/Mayo Hospital, Lahore, PAK

Corresponding author: Muhammad Youshay Jawad, youshay1995@gmail.com

\begin{abstract}
Borderline personality disorder (BPD) is a serious psychiatric condition characterized by dysfunctional relations, abnormal social behavior, and high morbidity. Many studies have implicated abnormal oxytocinergic system as a causative factor of behavioral dysregulation in BPD patients. The objective of this review is to provide a comprehensive analysis of the association of oxytocin with the pathogenesis of BPD and its possible role as a therapeutic agent. Our review indicates that a combination of genetic and environmental factors causes BPD patients to have lower baseline levels of oxytocin, leading to increased activation of the amygdala. This results in defective cognition of social stimuli, leading to abnormal behaviors like affective instability, unresolved attachment, and emotional dysregulation. Clinical trials conducted on BPD patients using intranasal oxytocin have shown both prosocial and trust-lowering effects. The effects of oxytocin depend upon various patient characteristics like the history of childhood trauma and the nature of attachment. Even though evidence of oxytocin's role in modulating behavior in BPD patients already exists, further studies are required to more clearly elaborate on this role to fully explore oxytocin's potential as a therapeutic agent.
\end{abstract}

Categories: Psychiatry, Psychology

Keywords: oxytocin, borderline personality disorder, clinical neuroscience, differential susceptibility

\section{Introduction And Background}

People suffering from personality disorders form the major share of patients receiving psychiatric care, and among all personality disorders, borderline personality disorder (BPD) is the most commonly treated issue along with schizotypal personality disorder [1]. The psychopathological domains of BPD can be very well illustrated along three lines: disturbed relatedness (unstable relationships, identity disturbance, and a chronic feeling of emptiness); behavioral dysregulation (impulsivity and suicidal/self-mutilative behavior); and affective dysregulation (affective instability, inappropriate anger, and efforts to avoid abandonment) [2]. Affective instability refers to multiple mood changes within a single day, ranging from euphoria to dysphoria, and anger outbursts followed by feelings of guilt often targeted toward caregivers [3]. This affective instability was the most common criterion present at baseline as well as after two years in clinically diagnosed BPD patients as per a study [4]. BPD patients face stigma not only in society but in psychiatric and mental health units as well. These patients have several negative connotations attached to them, which lead to mental health clinicians having a negative attitude toward them; in fact, a minority of clinicians prefer to not work with BPD patients [5].

The pathogenesis of BPD, similar to other psychiatric conditions, is multifactorial, often due to interactions between the environment and genetic components. Moreover, most of the causes are transdiagnostic, which is common among various psychiatric conditions [6]. One promising pathological factor for research is the oxytocinergic system in the brain, the interest in which was triggered by the publication of comparative studies showing low oxytocin levels in BPD patients as compared to controls [7]. This review focuses on the latest literature on the role of oxytocin, its genetics, receptor polymorphism, and how it interacts with the environment and early abuse to cause BPD. This review will also summarize the findings of various clinical trials that used intranasal oxytocin to alleviate BPD symptoms. for the benefit of the general mental health community.

\section{Review}

\section{Method}

We searched PubMed for relevant articles on January 25, 2021, by employing the following terms: "Oxytocin” AND “Borderline Personality Disorder”, "Borderline Personality Disorder” AND “Oxytocin”, and “Oxytocin” AND "Borderline"*

\section{Results}

These PubMed searches yielded 62 results. After going through all search results, all review studies were excluded and only original studies were included in this review. After careful consideration and going through all the remaining results, 22 articles were selected, including nine clinical trials, to conduct a literature review to understand the association between oxytocin and BPD.

This review focuses on the latest literature on the role of oxytocin, its genetics, receptor polymorphism, and 
how it interacts with the environment and early abuse to cause BPD. This review will also summarize the findings from the clinical trials that used intranasal oxytocin to alleviate various BPD symptoms.

\section{Discussion}

Oxytocin in Psychoneuroendocrinology

Many neuropeptide hormones have been studied regarding their association with BPD, but the one that has captured our interest is oxytocin. Oxytocin, a neuropeptide hormone, is often portrayed as a love hormone and has been found to have a role in how we perceive ourselves, remember our past relationships, socially interact, and manage stress, especially in the previously mentioned domains, thereby making it an important candidate to be analyzed pertaining to various psychiatric illnesses including BPD [8].

Oxytocin Receptor and Its Genes

Not only are oxytocin levels lower in BPD, but the oxytocin receptor (OXTR) expression is decreased as well, showing the role of oxytocin and its receptor in this disorder [9]. It is important to not see OXTR from an angle of "diathesis-stress"; we should rather see it from an angle of "differential susceptibility" (also known as "plasticity"). Many single nucleotide polymorphisms (SNP) have been identified and linked with BPD, but OXTR rs 53576 having alleles A and G (AA/AG vs. GG) has shown the most consistent results. Differential susceptibility tells us that having a particular allele will make a person more susceptible to positive outcomes in the presence of a positive environment and worse outcomes in the presence of a bad environment. Several studies have identified that people with genotype AA/AG showed a linear relationship of developing BPD with early adverse events, whereas people with genotype GG showed no relationship of developing illness with early adverse events, thus reinforcing the role of the OXTR gene in plasticity [10,11]. It has also been reported that childhood maltreatment in the AA/AG subgroup leads to more empathy towards psychological pain while the GG subgroup remained unaffected by childhood maltreatment; therefore, it is hypothesized that the OXTR gene has a role in disproportionately increased empathy towards psychological pain in BPD patients as compared to controls, with this disproportionality leading to disturbed relatedness. In short, AA/AG genotypes are at lower risk than normal of developing BPD in the presence of early parental warmth, and at the same time, they are at a higher risk than normal of developing psychopathology in presence of early childhood abuse [12].

Role in Neural Circuits

Bottom-up and top-down neural circuitry is often involved in normal emotional processing, and mostly it is the synthesis of these two processes that leads to a balanced approach to emotional reactivity. The topdown pathway includes the prefrontal cortex and its associated regions, whereas the bottom-up pathway is handled by the amygdala and para-amygdala regions. The role of the prefrontal cortex is important in attenuating most of our feelings; moreover, it also helps to make sense of what we feel and why do we feel it in response to some particular stimuli [13]. Patients with BPD show structural and functional abnormalities in a fronto-limbic network with limbic hyperreactivity (more bottom-up pathway), and less control on it from the prefrontal cortex, leading to impulsivity, affective dysregulation, and other core features of BPD [14]. Intranasal oxytocin has been shown to decrease limbic hyperreactivity regardless of scenic valence, with no effects on either the prefrontal cortex or fronto-limbic pathway; hence, it is hypothesized that oxytocin administration can attenuate the interpersonal bias, leading to the aversive interpretation of neutral stimuli and often affective instability. It also reiterates the prosocial and anxiolytic effects of oxytocin on our neural connections $[15,16]$.

Oxytocin and Attachment

The early attachment of a child to a caregiver is an important phase, and caregiver separation in the first five years of the life of a child can lead to disorganized (unresolved) types of attachment later in life, a characteristic pattern of attachment normally seen in the majority of BPD patients [17]. Oxytocin has been shown to have a role in mother-infant bonding as well as social bonding, and hence one can speculate on its association with specific attachment styles [8]. It has been shown in studies that exclusion from an environment can lead to a change in oxytocin levels having a role in alleviating separation pain and mending broken relationships. Borderline patients, specifically the ones with unresolved attachments, have been shown to have a significant decrease in oxytocin levels after separation rather than a normal increase in controls, elucidating the role of oxytocin in higher rejection sensitivity with greater efforts to avoid abandonment in this patient group [18]. This also emphasizes the strong link of oxytocin with respect to the early environment of a child. In a study, borderline patients having a high fear of compassion (FOC) were associated with lower oxytocin levels. High FOC leads to various interpersonal issues among BPD patients. The same set of patients with high FOC had aversive and harsh recalling of their parenting. On the other hand, recalling emotional warmth from parents was positively correlated with higher oxytocin levels in another subset of BPD patients. It again asserts that oxytocin has a greater role in the subset of BPD patients having unresolved attachment issues arising from early childhood abuse [19].

Limitations of Basic Studies

The biggest limitation that could be observed in the studies we reviewed was the methodological inconsistency in finding the correct way to measure oxytocin and the issue as to whether peripheral oxytocin values could relate to central values [20]. The number of patients was fewer in earlier studies, but the latest studies had enough participants to ensure statistical significance $[13,15]$. It is important to classify BPD patients into phenotypes with prominent core features and dysfunctions since, over time, a certain core 
feature starts to dominate within a patient, and then study them on the association with oxytocin level and receptor polymorphism to ensure better translational research [3]. It is important to understand that oxytocin has a transdiagnostic role in psychiatric diseases often studied with autism, depression, and personality disorder; therefore, it is important to find out what are the core features that it impacts, and how it forms overall pathology through interaction with other neuropeptides, hormones, and neural connections along with gender differences concerning hormones and neuropeptides [21,22].

Clinical Trials With Oxytocin

To date, there have only been a limited number of studies performed to investigate the therapeutic effects of oxytocin administration on BPD patients (Table 1). These studies have yielded important results regarding the ability of oxytocin to modulate the behavior of patients, although many questions still remain unanswered. In many cases, oxytocin has a prosocial effect on BPD patients, normalizing their defective processing of social cues and thereby improving their interpersonal communication. Significant results to this effect were shown by Bertsch et al. (2013) [23], who showed that a single dose of oxytocin reduced the hyperactivation of the amygdala in BPD patients, thereby normalizing their attention bias to negative social cues. A similar study by Lischke et al. (2017) also demonstrated decreased paralimbic activation in BPD patients following oxytocin administration, although amygdala activity in healthy controls was found to be increased [15]. In a different study, however, Brüne et al. (2013) demonstrated that BPD patients had an avoidant response to angry faces, which was abolished by intranasal oxytocin administration [24]. Increased attention towards threatening stimuli due to the hyperactive amygdala has been linked with increased stress reactivity and cortisol response in BPD patients. Oxytocin was also shown to reduce stress-induced cortisol surge in BPD patients in a study by Simeon et al. (2010) [25]. BPD patients often show issues related to empathy, leading to difficulty in maintaining stable interpersonal relationships. In a study carried out by Domes et al. (2010) [26], oxytocin improved affective empathy and approach motivation in BPD patients. Thus, oxytocin's ability to improve the processing of social cues, affective empathy, and approach motivation is a promising starting point to investigate its role further in improving dysregulated social behavior in BPD patients. Studies carried out by Schneider et al. (2020) [27] and Brüne et al. (2015) [28] have also demonstrated improvements in dysregulated behavior of BPD patients, by abolishing incongruent and flight behavior respectively, thus making their behavior similar to controls. However, oxytocin does not always have prosocial effects. In two different studies carried out by Bartz et al. (2011) [29] and Ebert et al. (2020) [30], oxytocin was shown to reduce trust among BPD patients. Interestingly, in both these studies, the reduction of trust depended on other features of BPD patients' personalities. For example, Ebert et al. found a significant correlation between childhood trauma scores and the reduction of trust. Similarly, although oxytocin administration increased trust among anxiously-attached, low-avoidant participants in the study by Bartz et al., it caused a significant decrease in trust among patients with anxiously-attached, rejectionsensitive attachment patterns. These results indicate that oxytocin does not always have a prosocial effect on patients; rather, its effect is modulated by various factors.

There are different reasons as to why oxytocin's effect on different patients might be different. One possibility is that negative experiences cause dysregulation of the oxytocin system in patients. Oxytocin's differential effect on different patients may be caused by neurobiological differences, e.g., differences in genetic susceptibility. Another possibility is that oxytocin modulates behavior by increasing the salience of social cues, which may result in triggering a range of different behaviors, both positive and negative, depending on the social context and individual differences in processing different stimuli [31]. Oxytocin's effect may also depend on the presence of different comorbidities in different patients; thus, oxytocin does not always lead to an improvement in interpersonal behavior in patients with BPD; rather, its effect varies according to a person's unique characteristics. Although yielding useful results, most of the studies carried out to see the effect of oxytocin on BPD patients are limited in their extent due to their small sample sizes and the fact that most of them consisted of women participants only. Since the effect of exogenous oxytocin may be different in women and men, these studies need to be replicated with larger sample sizes and the inclusion of more men. The effect of comorbidities such as depression, obsessive-compulsive disorder (OCD), eating disorder, and post-traumatic stress disorder (PTSD) on oxytocin's efficacy also needs to be investigated.

Many of the BPD patients included in these studies were simultaneously using psychoactive medications [various selective serotonin reuptake inhibitors (SSRIs) or atypical antipsychotics]; therefore, interactions of oxytocin with these medications cannot be excluded. Dose-dependent effects of oxytocin need to be investigated too. These studies did not control for variations in baseline serum oxytocin levels, although these levels tend to vary, especially in people with a history of child abuse. Future studies are warranted to examine more deeply the effect of oxytocin on the behavioral, neurological, and genetic levels, preferably after prolonged and repeated administration or with other adjunct treatments, to more fully explore the potential of oxytocin as a therapeutic agent for BPD patients.

\section{Study limitations}

One limitation of this study is that specific keywords related to oxytocin and BPD were searched on only one database (PubMed). Any topics not related to those mentioned above are beyond the scope of this study. In addition, a systematic review of the topic was not completed. Also, a quality assessment of the included studies was not performed. Table 1 presents a summary of studies performed to investigate the therapeutic effects of oxytocin administration on BPD patients. 


\section{Cureus}

\begin{tabular}{|c|c|c|c|c|c|c|c|c|c|}
\hline \multirow[t]{2}{*}{ Study } & \multirow[t]{2}{*}{$\begin{array}{l}\text { average } \\
\text { age } \\
\text { (years) }\end{array}$} & \multirow[t]{2}{*}{$\begin{array}{l}\text { average } \\
\text { age } \\
\text { (years) }\end{array}$} & \multirow[t]{2}{*}{ assessment } & \multirow[t]{2}{*}{ medication } & \multirow[t]{2}{*}{ Menstrual phase } & \multicolumn{2}{|l|}{ Exclusion criteria } & \multirow[t]{2}{*}{$\begin{array}{l}\text { administration } \\
\text { and analysis } \\
\text { of effects }\end{array}$} & \multirow[t]{2}{*}{ Main fi } \\
\hline & & & & & & For BPD patients & For controls & & \\
\hline $\begin{array}{l}\text { Brüne et } \\
\text { al. (2013) } \\
\text { [24] }\end{array}$ & $\begin{array}{l}13(8 \mathrm{~F}+ \\
5 \mathrm{M}), 28.6 \\
\pm 7.22\end{array}$ & $\begin{array}{l}13(10 \mathrm{~F}+ \\
3 \mathrm{M}), 25.7 \\
\pm 6.76\end{array}$ & $\begin{array}{l}\text { Mini- } \\
\text { International } \\
\text { Neuropsychiatric } \\
\text { Interview }\end{array}$ & $\begin{array}{l}\text { Most patients } \\
\text { received } \\
\text { psychotropic } \\
\text { medication, mainly } \\
\text { SSRIs (number } \\
\text { unspecified) }\end{array}$ & $\begin{array}{l}\text { All females used oral } \\
\text { contraceptives }\end{array}$ & $\begin{array}{l}\text { Excessive smokers; } \\
\text { those who participated } \\
\text { in another study within } \\
30 \text { days prior to } \\
\text { screening; substance } \\
\text { dependence; } \\
\text { pregnancy; } \\
\text { breastfeeding; } \\
\text { intending to become } \\
\text { pregnant within } 30 \text { days } \\
\text { of completing the } \\
\text { study; prolactin level of } \\
>200 \text { ng/ml at baseline; } \\
\text { clinically significant } \\
\text { ECG abnormalities at } \\
\text { screening; acute, } \\
\text { serious, or unstable } \\
\text { medical conditions }\end{array}$ & Not specified & 45 minutes & $\begin{array}{l}\text { Avoidal } \\
\text { respon: } \\
\text { angry fi } \\
\text { BPD pe } \\
\text { abolish } \\
\text { OT } \\
\text { adminis }\end{array}$ \\
\hline $\begin{array}{l}\text { Domes et } \\
\text { al. (2019) } \\
\text { [26] }\end{array}$ & $\begin{array}{l}61, \text { age } \\
\text { not } \\
\text { specified }\end{array}$ & $\begin{array}{l}68, \text { age } \\
\text { not } \\
\text { specified }\end{array}$ & $\begin{array}{l}\text { Mini- } \\
\text { International } \\
\text { Neuropsychiatric } \\
\text { Interview and } \\
\text { SCID-II }\end{array}$ & $\begin{array}{l}27 \text { patients taking } \\
\text { antidepressant } \\
\text { medication, } 9 \\
\text { taking atypical } \\
\text { antipsychotics }\end{array}$ & $\begin{array}{l}\text { Mid-luteal phase, free of } \\
\text { hormonal contraception } \\
\text { for at least } 3 \text { months }\end{array}$ & $\begin{array}{l}\text { Pregnant or } \\
\text { breastfeeding women; } \\
\text { lifetime bipolar } \\
\text { disorder; lifetime } \\
\text { schizophrenia; current } \\
\text { alcohol or substance } \\
\text { addiction; patients } \\
\text { taking benzodiazepines }\end{array}$ & $\begin{array}{l}\text { Any Axis I } \\
\text { and II } \\
\text { psychiatric } \\
\text { disorder }\end{array}$ & 45 minutes & $\begin{array}{l}\text { OT } \\
\text { adminis } \\
\text { normali } \\
\text { affectiv } \\
\text { empatr } \\
\text { (partict } \\
\text { for pos } \\
\text { stimuli) } \\
\text { approa } \\
\text { motivat } \\
\text { behavic } \\
\text { BPD pe } \\
\text { with } \\
\text { differer } \\
\text { effect c } \\
\text { groups } \\
\text { effectiv } \\
\text { BPD pe }\end{array}$ \\
\hline $\begin{array}{l}\text { Schneider } \\
\text { et al. } \\
\text { (2020) } \\
{[27]}\end{array}$ & $\begin{array}{l}53 \mathrm{~F} \\
30.19 \\
\pm 7.51\end{array}$ & $\begin{array}{l}61 \mathrm{~F} \\
28.36 \\
\pm 7.65\end{array}$ & SCID-I and IPDE & $\begin{array}{l}\text { The participants } \\
\text { had to be free of } \\
\text { psychotropic } \\
\text { medication for at } \\
\text { least } 2 \text { weeks } \\
\text { before } \\
\text { participation }\end{array}$ & $\begin{array}{l}\text { No data on hormonal } \\
\text { contraception/menstrual } \\
\text { phase }\end{array}$ & $\begin{array}{l}\text { Current and lifetime } \\
\text { diagnosis of bipolar } \\
\text { disorder, schizophrenia, } \\
\text { and schizoaffective } \\
\text { disorder; alcohol or } \\
\text { drug (nicotine excluded) } \\
\text { dependence over the } \\
\text { last } 12 \text { months; } \\
\text { pregnancy; severe } \\
\text { medical illness; severe } \\
\text { visual handicap; } \\
\text { neurological disorders; } \\
\text { organic brain damage }\end{array}$ & Not specified & 75 minutes & $\begin{array}{l}\text { Incongl } \\
\text { behavic } \\
\text { becamı } \\
\text { slower } \\
\text { followir } \\
\text { adminis } \\
\text { in both } \\
\text { patient: } \\
\text { HC, thu } \\
\text { overcol } \\
\text { the defi } \\
\text { avoidar } \\
\text { behavic } \\
\text { BPD pe } \\
\text { No diffe } \\
\text { effect c } \\
\text { on diffe } \\
\text { groups }\end{array}$ \\
\hline $\begin{array}{l}\text { Bertsch } \\
\text { et al. } \\
\text { (2013) } \\
{[23]}\end{array}$ & $\begin{array}{l}40 F, 24.4 \\
\pm 4.7\end{array}$ & $\begin{array}{l}41 \mathrm{~F}, 24.4 \\
\pm 4.7\end{array}$ & SCID-I and II & None & Early follicular phase & $\begin{array}{l}\text { IQ less than or equal to } \\
85 ; \text { pregnancy; } \\
\text { endocrinal or } \\
\text { neurological disorders; } \\
\text { use of any type of } \\
\text { regular medication } \\
\text { except contraceptives; } \\
\text { lifetime diagnoses of } \\
\text { schizophrenia, } \\
\text { schizoaffective } \\
\text { disorder, or bipolar }\end{array}$ & $\begin{array}{l}\text { Current or } \\
\text { past } \\
\text { psychiatric } \\
\text { diagnoses } \\
\text { and } \\
\text { psychological } \\
\text { or psychiatric } \\
\text { treatment }\end{array}$ & 45 minutes & $\begin{array}{l}\text { OT } \\
\text { adminis } \\
\text { reduce } \\
\text { amygdi } \\
\text { activati } \\
\text { attentic } \\
\text { to nege } \\
\text { social s } \\
\text { in BPD }\end{array}$ \\
\hline
\end{tabular}




\section{Cureus}

\begin{tabular}{|c|c|c|c|c|c|c|c|c|c|}
\hline & & & & & & $\begin{array}{l}\text { disorder; current } \\
\text { alcohol or drug } \\
\text { dependence }\end{array}$ & & & patient: \\
\hline $\begin{array}{l}\text { Lischke } \\
\text { et al. } \\
\text { (2017) } \\
{[15]}\end{array}$ & $\begin{array}{l}51 F ; \\
\text { placebo: } \\
26.5 \\
\pm 5.52 ; \\
\text { oxytocin: } \\
26.43 \\
\pm 6.24\end{array}$ & $\begin{array}{l}48 F ; \\
\text { placebo: } \\
25.25 \\
\pm 4.41 ; \\
\text { oxytocin: } \\
23.23 \\
\pm 2.27\end{array}$ & $\begin{array}{l}\text { Structured } \\
\text { interviews }\end{array}$ & None & $\begin{array}{l}5 \text { HC, } 5 \text { BPD patients } \\
\text { taking hormonal } \\
\text { contraceptives tested } \\
\text { during the } \\
\text { contraceptive-free } \\
\text { period, the rest tested } \\
\text { during the early follicular } \\
\text { phase of the menstrual } \\
\text { cycle }\end{array}$ & $\begin{array}{l}\text { Participants who met } \\
\text { DSM-IV diagnostic } \\
\text { criteria for } \\
\text { schizoaffective } \\
\text { disorder, schizophrenia, } \\
\text { or intellectual disability; } \\
\text { received regular } \\
\text { medication within the } \\
\text { last } 8 \text { weeks or acute } \\
\text { medication within the } \\
\text { previous week before } \\
\text { study enrollment; } \\
\text { pregnancy, lactation, } \\
\text { menstrual irregularities, } \\
\text { or menopause at the } \\
\text { time of testing }\end{array}$ & $\begin{array}{l}\text { Participants } \\
\text { who met } \\
\text { DSM-IV } \\
\text { criteria for } \\
\text { current or } \\
\text { lifetime } \\
\text { diagnoses of } \\
\text { any Axis I or } \\
\text { Axis II } \\
\text { disorder; } \\
\text { pregnancy, } \\
\text { lactation, } \\
\text { menstrual } \\
\text { irregularities, } \\
\text { or } \\
\text { menopause } \\
\text { at the time of } \\
\text { testing }\end{array}$ & 45 minutes & $\begin{array}{l}\text { Decrea } \\
\text { paralim } \\
\text { brain } \\
\text { activati } \\
\text { normali } \\
\text { of abnc } \\
\text { fixation } \\
\text { behavic } \\
\text { BPD pa } \\
\text { followir } \\
\text { adminis } \\
\text { Increas } \\
\text { insular } \\
\text { amygdi } \\
\text { activati } \\
\text { followir } \\
\text { adminis } \\
\text { in HCs, } \\
\text { irrespe } \\
\text { emotiol } \\
\text { stimuli }\end{array}$ \\
\hline $\begin{array}{l}\text { Simeon et } \\
\text { al. (2011) } \\
\text { [25] }\end{array}$ & $\begin{array}{l}6 \mathrm{~F}+8 \mathrm{M}, \\
35.1 \pm 8.0\end{array}$ & $\begin{array}{l}9 \mathrm{~F}+4 \mathrm{M}, \\
34.5 \pm 8.9\end{array}$ & SCID-I and II & None & Not specified & $\begin{array}{l}\text { Lifetime schizophrenia } \\
\text { or bipolar I disorder; } \\
\text { mental retardation; } \\
\text { major medical or } \\
\text { neurological illnesses; } \\
\text { taking psychotropic or } \\
\text { other medications } \\
\text { including oral } \\
\text { contraceptives within } \\
\text { the past } 2 \text { weeks (5 } \\
\text { weeks for fluoxetine); } \\
\text { current major } \\
\text { depression, substance } \\
\text { use disorder, or eating } \\
\text { disorder; currently } \\
\text { pregnant, lactating, or } \\
\text { menopausal; regular } \\
\text { smokers }\end{array}$ & -- & $\begin{array}{l}30,60 \text {, and } 80 \\
\text { minutes }\end{array}$ & $\begin{array}{l}\text { OT } \\
\text { adminis } \\
\text { abolish } \\
\text { greater } \\
\text { dyspho } \\
\text { cortisol } \\
\text { in BPD } \\
\text { patient: } \\
\text { followir } \\
\text { stress } \\
\text { differer } \\
\text { effect C } \\
\text { oxytoci } \\
\text { stress } \\
\text { attenua }\end{array}$ \\
\hline \multirow[t]{2}{*}{$\begin{array}{l}\text { Bartz et } \\
\text { al. (2011) } \\
\text { [29] }\end{array}$} & \multirow[t]{2}{*}{$\begin{array}{l}10 \mathrm{~F}+ \\
4 \mathrm{M}, 35 \\
\pm 8\end{array}$} & \multirow[t]{2}{*}{$\begin{array}{l}6 \mathrm{~F}+7 \mathrm{M}, \\
35 \pm 8\end{array}$} & \multirow[t]{2}{*}{ SCID-I and II } & \multirow[t]{2}{*}{ None } & \multirow[t]{2}{*}{ Not specified } & $\begin{array}{l}\text { Psychotropic or other } \\
\text { medications for at least } \\
2 \text { weeks prior to the } \\
\text { study ( } 5 \text { weeks for } \\
\text { fluoxetine); current } \\
\text { substance use disorder, } \\
\text { major depression or } \\
\text { eating disorders } \\
\text { (anorexia or bulimia); } \\
\text { lifetime schizophrenia } \\
\text { or bipolar I disorder; } \\
\text { mental retardation and } \\
\text { medical or neurological } \\
\text { illness; pregnant, } \\
\text { lactating, or } \\
\text { menopausal females }\end{array}$ & $\begin{array}{l}\text { Any lifetime } \\
\text { Axis I or II } \\
\text { disorders }\end{array}$ & 35 minutes & $\begin{array}{l}\text { OT rest } \\
\text { signific } \\
\text { less tru } \\
\text { expecti } \\
\text { and } \\
\text { cooper } \\
\text { for anxi } \\
\text { attach } \\
\text { rejectio } \\
\text { sensiti } \\
\text { partici } \\
\text { but no } \\
\text { on less } \\
\text { anxious } \\
\text { attach } € \\
\text { particip } \\
\text { OXT pr } \\
\text { cooper } \\
\text { anxious } \\
\text { attach } \\
\text { avoidar } \\
\text { particip } \\
\text { (intima } \\
\text { seekers }\end{array}$ \\
\hline & & & & & & $\begin{array}{l}\text { Pregnancy; } \\
\text { breastfeeding; } \\
\text { addiction to alcohol or } \\
\text { illegal drugs; excessive } \\
\text { smoking; ECG }\end{array}$ & & & $\begin{array}{l}\text { Decrea } \\
\text { trust in }\end{array}$ \\
\hline
\end{tabular}




\section{Cureus}

\begin{tabular}{|c|c|c|c|c|c|c|c|c|c|}
\hline $\begin{array}{l}\text { Ebert et } \\
\text { al. (2013) } \\
\text { [30] }\end{array}$ & $\begin{array}{l}5 \mathrm{M}+8 \mathrm{~F} \\
28.6\end{array}$ & $\begin{array}{l}3 \mathrm{M}+ \\
10 \mathrm{~F}, 25.7\end{array}$ & SCID & $\begin{array}{l}11 \text { patients taking } \\
\text { SSRI/melatonergic } \\
\text { antidepressants }\end{array}$ & $\begin{array}{l}\text { All female participants } \\
\text { used oral contraceptives }\end{array}$ & $\begin{array}{l}\text { abnormalities; recent } \\
\text { illnesses; stable } \\
\text { psychopharmacological } \\
\text { medication was } \\
\text { accepted if remained } \\
\text { unchanged between } \\
\text { sessions }\end{array}$ & $\begin{array}{l}\text { Any } \\
\text { psychiatric } \\
\text { disorders }\end{array}$ & 30 minutes & $\begin{array}{l}\text { trauma } \\
\text { patient: } \\
\text { followir } \\
\text { adminis }\end{array}$ \\
\hline $\begin{array}{l}\text { Brüne et } \\
\text { al. (2015) } \\
{[28]}\end{array}$ & $\begin{array}{l}5 \mathrm{M}+ \\
10 \mathrm{~F}, 27.5 \\
\pm 7.3\end{array}$ & $\begin{array}{l}5 \mathrm{M}+ \\
10 \mathrm{~F}, 25.7 \\
\pm 6.4\end{array}$ & SCID-I and II & $\begin{array}{l}11 \text { patients taking } \\
\text { SSRI/melatonergic } \\
\text { antidepressants }\end{array}$ & Not specified & $\begin{array}{l}\text { Excessive smoking; } \\
\text { participation in another } \\
\text { study within } 30 \text { days } \\
\text { before screening; a } \\
\text { history of substance } \\
\text { dependence; } \\
\text { pregnancy or intention } \\
\text { to become pregnant } \\
\text { within } 30 \text { days of } \\
\text { completing the study; } \\
\text { current breastfeeding; } \\
\text { prolactin level of }>200 \\
\text { ng/ml at baseline; } \\
\text { clinically significant } \\
\text { ECG abnormalities; any } \\
\text { acute, serious, or } \\
\text { unstable medical } \\
\text { condition }\end{array}$ & $\begin{array}{l}\text { Any } \\
\text { psychiatric } \\
\text { disorders }\end{array}$ & Not specified & $\begin{array}{l}\text { OT incr } \\
\text { affiliati } \\
\text { behavic } \\
\text { control } \\
\text { given a } \\
\text { but not } \\
\text { such ef } \\
\text { was se } \\
\text { BPD pe } \\
\text { Flight b } \\
\text { was } \\
\text { diminis } \\
\text { both H' } \\
\text { BPD af } \\
\text { adminis } \\
\text { at T1 b। } \\
\text { at T2 }\end{array}$ \\
\hline
\end{tabular}

TABLE 1: A summary of intranasal oxytocin clinical trials

M: males; f: female; OT: oxytocin; HC: healthy controls; BPD: borderline personality disorder; SCID-I: Structured Clinical Interview for Diagnostic and Statistical Manual-Fourth Edition Axis I Disorders; SCID-II: Structured Clinical Interview for Diagnostic and Statistical Manual-Fourth Edition Axis II Disorders; IPDE: International Personality Disorder Examination; SSRI: selective serotonin reuptake inhibitor; ECG: electrocardiogram; DSM IV: The Diagnostic and Statistical Manual of Mental Disorders-Fourth Edition

\section{Conclusions}

In this study, we tried to capture the role of oxytocin in the pathogenesis of BPD through a review of the relevant clinical trials. Like all psychiatric diseases, an eclectic model towards BPD has to be considered, which will include genetics, gene-environment interactions, and psychological and sociological factors. Oxytocin is an important factor in all of these domains. Our study also delineates the importance of geneenvironment interactions and the role of the oxytocinergic system in plasticity (susceptibility model). Based on the various studies we examined, no one hit model can be devised for BPD; rather, various factors combine together to finally lead to an individual towards this disorder. Further studies of these factors along with oxytocin and other neuropeptide hormones can help us to understand the pathogenesis and develop new therapeutic models to treat the morbidity of BPD. We have pointed out that specific phenotypes of BPD having unresolved attachment have greater defects in the oxytocinergic system as compared to other BPD phenotypes. Similarly, clinical trials have shown that some symptoms improved more than others in various BPD patients. These findings provide us with a good avenue to perform more studies on personalized medicine to target specific domains responsive to oxytocin adjunct with other psychoactive medications and psychotherapies.

\section{Additional Information}

\section{Disclosures}

Conflicts of interest: In compliance with the ICMJE uniform disclosure form, all authors declare the following: Payment/services info: All authors have declared that no financial support was received from any organization for the submitted work. Financial relationships: All authors have declared that they have no financial relationships at present or within the previous three years with any organizations that might have an interest in the submitted work. Other relationships: All authors have declared that there are no other relationships or activities that could appear to have influenced the submitted work.

\section{References}

1. Bender DS, Dolan RT, Skodol AE, et al.: Treatment utilization by patients with personality disorders . Am J Psychiatry. 2001, 158:295-302. 10.1176/appi.ajp.158.2.295

2. Sanislow CA, Grilo CM, McGlashan TH: Factor analysis of the DSM-III-R borderline personality disorder criteria in psychiatric inpatients. Am J Psychiatry. 2000, 157:1629-1633. 10.1176/appi.ajp.157.10.1629

3. Renaud SM, Zacchia C: Toward a definition of affective instability . Harv Rev Psychiatry. 2012, 20:298-308. 10.3109/10673229.2012.747798

4. McGlashan TH, Grilo CM, Sanislow CA, et al.: Two-year prevalence and stability of individual DSM-IV criteria for schizotypal, borderline, avoidant, and obsessive-compulsive personality disorders: toward a hybrid model of axis II disorders. Am J Psychiatry. 2005, 162:883-889. 10.1176/appi.ajp.162.5.883

5. Black DW, Pfohl B, Blum N, et al.: Attitudes toward borderline personality disorder: a survey of 706 mental health clinicians. CNS Spectr. 2011, 16:67-74. 10.1017/\$109285291200020X 
6. Gunderson JG, Herpertz SC, Skodol AE, Torgersen S, Zanarini MC: Borderline personality disorder. Nat Rev Dis Primers. 2018, 4:18029. 10.1038/nrdp.2018.29

7. Bertsch K, Schmidinger I, Neumann ID, Herpertz SC: Reduced plasma oxytocin levels in female patients with borderline personality disorder. Horm Behav. 2013, 63:424-429. 10.1016/j.yhbeh.2012.11.013

8. Olff M, Frijling JL, Kubzansky LD, et al.: The role of oxytocin in social bonding, stress regulation and mental health: an update on the moderating effects of context and interindividual differences. Psychoneuroendocrinology. 2013, 38:1883-1894. 10.1016/i.psyneuen.2013.06.019

9. Carrasco JL, Buenache E, MacDowell KS, et al.: Decreased oxytocin plasma levels and oxytocin receptor expression in borderline personality disorder. Acta Psychiatr Scand. 2020, 142:319-325. 10.1111/acps.13222

10. Hammen C, Bower JE, Cole SW: Oxytocin receptor gene variation and differential susceptibility to family environment in predicting youth borderline symptoms. J Pers Disord. 2015, 29:177-192. 10.1521/pedi_2014_28_152

11. Zhang M, Liu N, Chen $\mathrm{H}$, Zhang N: Oxytocin receptor gene, childhood maltreatment and borderline personality disorder features among male inmates in China. BMC Psychiatry. 2020, 20:332. 10.1186/s12888020-02710-0

12. Flasbeck V, Moser D, Kumsta R, Brüne M: The OXTR single-nucleotide polymorphism rs 53576 moderates the impact of childhood maltreatment on empathy for social pain in female participants: evidence for differential susceptibility. Front Psychiatry. 2018, 9:359. 10.3389/fpsyt.2018.00359

13. Ochsner KN, Ray RR, Hughes B, et al.: Bottom-up and top-down processes in emotion generation: common and distinct neural mechanisms. Psychol Sci. 2009, 20:1322-1331. 10.1111/j.1467-9280.2009.02459.x

14. Krause-Utz A, Winter D, Niedtfeld I, Schmahl C: The latest neuroimaging findings in borderline personality disorder. Curr Psychiatry Rep. 2014, 16:438. 10.1007/s11920-014-0438-z

15. Lischke A, Herpertz SC, Berger C, Domes G, Gamer M: Divergent effects of oxytocin on (para-)limbic reactivity to emotional and neutral scenes in females with and without borderline personality disorder. Soc Cogn Affect Neurosci. 2017, 12:1783-1792. 10.1093/scan/nsx107

16. Barnow S, Stopsack M, Grabe HJ, Meinke C, Spitzer C, Kronmüller K, Sieswerda S: Interpersonal evaluation bias in borderline personality disorder. Behav Res Ther. 2009, 47:359-65. 10.1016/j.brat.2009.02.003

17. Steele H, Siever L: An attachment perspective on borderline personality disorder: advances in geneenvironment considerations. Curr Psychiatry Rep. 2010, 12:61-67. 10.1007/s11920-009-0091-0

18. Jobst A, Padberg F, Mauer MC, et al.: Lower oxytocin plasma levels in borderline patients with unresolved attachment representations. Front Hum Neurosci. 2016, 10:125. 10.3389/fnhum.2016.00125

19. Ebert A, Edel MA, Gilbert P, Brüne M: Endogenous oxytocin is associated with the experience of compassion and recalled upbringing in borderline personality disorder. Depress Anxiety. 2018, 35:50-57. 10.1002/da.22683

20. Freeman SM, Samineni S, Allen PC, Stockinger D, Bales KL, Hwa GG, Roberts JA: Plasma and CSF oxytocin levels after intranasal and intravenous oxytocin in awake macaques. Psychoneuroendocrinology. 2016, 66:185-194. 10.1016/j.psyneuen.2016.01.014

21. Herpertz SC, Bertsch K: A new perspective on the pathophysiology of borderline personality disorder: a model of the role of oxytocin. Am J Psychiatry. 2015, 172:840-851. 10.1176/appi.ajp.2015.15020216

22. Heinrichs M, Domes G: Neuropeptides and social behaviour: effects of oxytocin and vasopressin in humans . Prog Brain Res. 2008, 170:337-350. 10.1016/S0079-6123(08)00428-7

23. Bertsch K, Gamer M, Schmidt B, et al.: Oxytocin and reduction of social threat hypersensitivity in women with borderline personality disorder. Am J Psychiatry. 2013, 170:1169-1177. 10.1176/appi.ajp.2013.13020263

24. Brüne M, Ebert A, Kolb M, Tas C, Edel MA, Roser P: Oxytocin influences avoidant reactions to social threat in adults with borderline personality disorder. Hum Psychopharmacol. 2013, 28:552-561. 10.1002/hup.2343

25. Simeon D, Bartz J, Hamilton H, Crystal S, Braun A, Ketay S, Hollander E: Oxytocin administration attenuates stress reactivity in borderline personality disorder: a pilot study. Psychoneuroendocrinology. 2011, 36:1418-1421. 10.1016/j.psyneuen.2011.03.013

26. Domes G, Ower N, von Dawans B, et al.: Effects of intranasal oxytocin administration on empathy and approach motivation in women with borderline personality disorder: a randomized controlled trial. Transl Psychiatry. 2019, 9:328. 10.1038/s41398-019-0658-4

27. Schneider I, Boll S, Volman I, Roelofs K, Spohn A, Herpertz SC, Bertsch K: Oxytocin normalizes approachavoidance behavior in women with borderline personality disorder. Front Psychiatry. 2020, 11:120. 10.3389/fpsyt.2020.00120

28. Brüne M, Kolb M, Ebert A, Roser P, Edel MA: Nonverbal communication of patients with borderline personality disorder during clinical interviews: a double-blind placebo-controlled study using intranasal oxytocin. J Nerv Ment Dis. 2015, 203:107-111. 10.1097/NMD.0000000000000240

29. Bartz J, Simeon D, Hamilton H, et al.: Oxytocin can hinder trust and cooperation in borderline personality disorder. Soc Cogn Affect Neurosci. 2011, 6:556-563. 10.1093/scan/nsq085

30. Ebert A, Kolb M, Heller J, Edel MA, Roser P, Brüne M: Modulation of interpersonal trust in borderline personality disorder by intranasal oxytocin and childhood trauma. Soc Neurosci. 2013, 8:305-313. 10.1080/17470919.2013.807301

31. Bartz JA, Zaki J, Bolger N, Ochsner KN: Social effects of oxytocin in humans: context and person matter . Trends Cogn Sci. 2011, 15:301-309. 10.1016/j.tics.2011.05.002 